UDC 624.131

Olexij G. Rogozhin, D. S. (Economics), Principal researcher

ORCID ID 0000-0001-8101-9368 e-mail: olexarog@ gmail.com

Yevheniy O. Yakovlev, D. S., Principal researcher

e-mail: yakovlev@niss.gov.ua

Institute of Telecommunication and Global Information Space of NASU, Kyiv, Ukraine

\title{
ASSESSMENT OF ADDITIONAL SEISMIC RISK OF DESTRUCTION OF STRUCTURES ON FLOODED LOESSES AND LOESSY-LOAMY ROCKS IN UKRAINE
}

\begin{abstract}
Over the recent decades in Ukraine regional activation of flooding of lands, accompanied by landslide formation and subsidence of surfaces take place. In the years 1982-2004, in the southern regions of Ukraine, the areas of underflooding increased 9 times. Therefore the risk of destruction of structures from probable seismic shaking increases in large areas, which will provoke landslides and thixotropic dilution of flooded loesses. The article is devoted to the regional economic assessment of additional seismic risk of destruction of structures in Ukraine in areas of distribution of flooded loesses-rock formations. Obtained data on the modern activation of changes in the geological conditions of loesses and loessy-loamy rocks and increasing their contribution to the increase of ecological and geological risks of life lead to the important conclusion that loess-rock massifs in most regions of Ukraine become vulnerable elements of the geological environment to the impact of increasing technogenic load and global climate change. To strengthening the hazardous properties of loesses and loessyloamy rocks, in addition to subsidence, reduction of strength, etc., new processes have been added - activation of swelling and thixotropy. They are most active in cities and towns, which is caused by large losses of water and heat from urban networks, which reach 35-45\% and exceed the filtration capacity of loesses and loessy-loamy soils. In most cases, this leads to the formation of anthropogenic aquifers as a key factor in the mechanism of degradation loesses and loessy-loamy rocks in cities and the formation of hydro-geodeformation fields during seismic shocks. The consideration of climate parameters significantly changes the value of economic assessment of the additional risk of seismic destruction of structures on flooded loesses and loessy-loamy rocks in Ukraine towards its reduction at the locally objective level. It is also advisable to add the number of days with rain for the year and the number of days with non-freezing soil in winter (NovemberFebruary) to the climate parameters we consider at this stage. The rapid changes of the engineering-geological state of subsidence rock masses in the conditions of influence of factors of global climate change, the increase of global seismicity and technogenesis, in our opinion, require the development of new regulatory and methodological provisions for the study of loesses and loessy-loamy rocks formations in technogenic loaded and vulnerable regions of Ukraine.
\end{abstract}

Keywords: seismic risk; loesses; subsidence; engineering and geological conditions

(C) O.G. Rogozhin, Y.O. Yakovlev, 2019 


\title{
О.Г. Рогожин, С.О. Яковлев
}

Інститут телекомунікацій і глобального інформаційного простору НАН України, м. Київ, Україна

\section{ОЦІНКА ДОДАТКОВОГО СЕЙСМІЧНОГО РИЗИКУ РУЙНУВАННЯ СПОРУД НА ПІДТОПЛЕНИХ ЛЕСАХ ТА ЛЕСОВО-СУГЛИНИСТИХ ПОРОДАХ В УКРАЇНІ}

\begin{abstract}
Анотація. За 1982-2004 рр. в південних регіонах Украӥни площі підтоплення зросли у 9 разів. Через че на великих територіях збільшується загроза руйнування споруд від імовірного сейсмічного струшування, щзо провокуватиме зсуви та тиксотропне розрідження підтоплених лесів. Стаття присвячена регіональній економічній оцінці додаткового сейсмічного ризику руйнування споруд в Украӥні в ареалах поширення підтоплених лесовопородних товщ. Отримані дані про сучасну активізацію змін інженерногеологічних умов лесів і лесово-суглинистих порід (ЛСП) та збільшення їх внеску у зростання еколого-геологічних ризиків життєдіяльності підводять до важливого висновку, що лесово-породні масиви у більшості регіонів Украӥни стають найбільш чутливим елементом геологічного середовища до впливу зростаючого техногенного навантаження та глобальних змін клімату. До посилення небезпечних властивостей лесів та ЛСП, крім просадковості, зменшення міцності тощо, додалися нові прощеси активізачія набухаємості, збільшення проявів пливуноутворення та тиксотропії. Найактивніше вони проявляються в містах $і$ селищах, що обумовлено великими втратами води і тепла з міських мереж, які сягають 35-45\% і перевищують фільтраиійну здатність лесів та ЛСП. У більшості випадків це призводить до формування техногенних водоносних горизонтів (так званих «верховодок») як ключового чинника в механізмі деградації лесово-породних товщ у містах та формування гідро-геодеформаџійних полів при сейсмопоштовхах. Врахування кліматичних параметрів істотно змінює значення економічної оиінки додаткового ризику сейсмічного руйнування споруд на підтоплених лесах $і$ ЛСП в Украӥні у бік його зменшення на локальнооб'єктовому рівні. До врахованих нами на иьвому етапі дослідження кліматичних параметрів доцільно додати також: кількість днів з дощем за рік та кількості днів із не замерзлим грунтом в зимовий період (листопад лютий). Швидкі зміни інженерно-геологічного стану просадкових породних масивів в умовах впливу чинників глобальних змін клімату, зростання глобальної сейсмічності та техногенезу, на наму думку, потребують розробки нових нормативно-методччних положень з вивчення лесових та лесово-породних формацій із виділенням їх опорних розрізів у техногенно навантажених та вразливих регіонах Украӥни.
\end{abstract}

Ключові слова: сейсмічний ризик; леси; просадковість; інженерно-геологічні умови

\section{Вступ}

В останні десятиліття провідним чинником зниження інженерносейсмогеологічної стійкості лесових товщ стає їх деградація під зовнішнім впливом підтоплення і засолення, спричиненого техногенно-господарською діяльністю та змінами клімату. Як було показано у $[1,2]$, ці фактори активізують негативні інженерно-геологічні властивості лесів і ЛСП, такі як розмокаємість, просадковість та тиксотропність. 
За 1982-2004 pр. в південних регіонах України площі підтоплення зросли у 9 разів [3, с. 188]. Через це на великих територіях збільшується загроза руйнування споруд від імовірного сейсмічного струшування, що провокуватиме зсуви та тиксотропне розрідження підтоплених лесів (перехід їх у пливунний стан внаслідок віброруйнування неводостійкої агрегатної структури лесового грунту).

Картометричний аналіз показав, що частка підтоплених лесів і лесовосуглинистих порід (ЛСП) в межах територій із сейсмічністю 6 балів і більше (від загальної площі лесів і ЛСП в Україні) становить понад 15\%. Частка населених пунктів (міст і сіл) на підтоплених лесах і ЛСП із сейсмічністю 6 балів і більше (від тих, що на всіх лесах і ЛСП в Україні) перевищує 18\%, а кількість населення в них (від населення на всіх лесах і ЛСП в Україні) наближається до 10\%.

Нашою метою на поточному етапі дослідження було виконати регіональну економічну оцінку додаткового сейсмічного ризику руйнування споруд в Україні в ареалах поширення підтоплених лесово-породних товщ, спричиненого їх специфічними геотехнічними властивостями. Оцінка здійснена методом картометричного аналізу з використанням інструментів ГІС ArcMap 9.3, поглиблюючи наші попередні дослідження загроз руйнування споруд, спричинених деградацією лесових і лесово-суглинистих порід в умовах змін клімату на території України.

\section{Техногенне підтоплення як фактор загрози руйнування споруд у містах}

У містах і промислових селищах геологічне середовище (ГС) в цілому разом 3 техногенною інфраструктурою (житлова і промислова забудова, водоенергетичні і транспортні комунікації тощо) утворюють складні техногенногеологічні системи (ТГС) «інженерні об’єкти міста - ГС». Саме ці ТГС є головним «депо» техногенних факторів впливу на леси та ЛСП, оскільки в їх межах розташована більшість промислово-міських агломерацій (ПМА) України.

Головною особливістю ГС в межах таких ПМА є його зростаючі зміни, внаслідок чого за своїми інженерно-геологічними, гідрогеологічними та геотехнічними параметрами ТГС у ПМА мають нестабільний характер за умов збереження техногенних навантажень (водно-балансових, теплових, геодинамічних та інших).

Регіональний аналіз складу змін у 1980-2015 pp. гідрогеологічних та інженерно-геологічних умов міст та селищ України, які впливають на безпеку життєдіяльності [12], засвідчив, що головним фактором їх погіршення та одночасного зростання ризику надзвичайних ситуацій (НС) в ПМА на лесовопросадкових грунтах є підтоплення територій.

Аналіз просторового розподілу ПМА показав, що формування більшості 3 них відбувалося за переважно рівнинного рельєфу на просадкових лесових і лесово-суглинистих грунтах (понад 50\% території України) зі зниженим поверхневим стоком. В таких умовах порушення природного водного i теплового балансу верхньої зони ГС в межах ПМА сприяло активному підйому рівнів грунтових вод (РГВ) і активізації процесу підтоплення міст $\mathrm{i}$ селищ. За останні 35 років загальна кількість підтоплених ПМА (понад 540) та площа підтоплення (до 200 тис. га, до 11\% загальної площі) зросли більше ніж в 2 рази. 
Про значний водно-геотехнічний вплив водопровідно-каналізаційних та теплових мереж (ВКТМ) міст та селищ на інженерно-геологічний стан ГС свідчить їх загальна середня щільність у ПМА, яка досягає 11,0 км/км². Причому протяжність водопровідних, каналізаційних та теплоенергетичних мереж у ПМА становить, відповідно: 127, 39 та 41 тис. км, 3 них 35-45\% в аварійному стані.

В зазначених умовах важливо те, що значна частка енергоспоживання ПМА пов'язана із забезпеченням функціонування ВКТМ, підвищені водні втрати 3 яких внаслідок незадовільної гідроізоляції впливають як на стійкий просторово-часовий підйом РГВ, так і на додаткові деформації залізобетонних конструкцій будівель з наступним прискоренням їх старіння і зношеності.

За сучасних втрат води в межах ПМА у приблизно 1,2 млрд м³/рік, додаткове техногенне живлення грунтового шару на площі міст та селищ (19,6 тис. км $\left.{ }^{2}\right)$ у середньому становить порядку:

$1,2 \cdot 10^{9} \mathrm{M}^{3} /$ рік $=19,6 \cdot 10^{3} \cdot 10^{6} \approx 0,062 \mathrm{M} \approx 62 \mathrm{Mм} /$ рік або 2,0 л/сек $\cdot \mathrm{\kappa м}^{2}$.

Це майже в 2 рази перевищує багаторічні регіональні значення інфільтраційного живлення підземних вод $(\sim 1,0$ л/сек·км²) і тому сприяє подальшому розвитку підтоплення міст та селищ.

Iз наведеного випливає обгрунтоване припущення, що в останні 2-3 десятиліття сучасний стан ВКТМ є головним фактором розвитку підтоплення житлових і промислових споруд у більшості ПМА України, а також - фактором зростання ризику надзвичайних ситуацій (НС) інженерно-геологічного та геотехнічного походження в ареалах поширення просадкових лесів та ЛСП.

\section{Геотехнічні механізми деградації підтоплених лесових товщ}

Згідно із результатами сучасних геотехнічних досліджень (фізико-хімічних, геофізичних, мікроскопічних тощо) головними причинами техногенної активізації просадкових процесів є вилуговування цементуючих карбонатних сполук із лесових та ЛСП та гідратація глинистих мінералів з їх переважним перетворенням у нестійкі колоїдні форми [13]. Це призводить до геомеханічної деградації порід піщано-глинистого складу i формування ділянок їх тиксотропного (пливуноподібного) стану. Показником такої деградації $\epsilon$ зростаюче утворення зсувів-потоків на схилових територіях лесово-породних масивів у більшості ПМА України (зокрема, у містах Дніпро, Кам'янське (кол. Дніпродзерджинськ), Чернівці, Куп’янськ, Київ, Херсон).

За окремими оцінками під час гідромеліоративних зйомок в Дніпровській області [13], було встановлено, що величина статичного напруження зрушення (CH3) перезволожених лесів у пливуноподібному стані становить

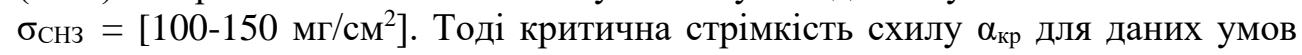
техногенних змін геомеханічних показників лесів орієнтовно становитиме:

$$
\begin{gathered}
\alpha_{\kappa p}^{\circ}=\operatorname{arctg} \frac{\sigma_{C H 3}}{\rho \cdot \Delta h} ; \\
\alpha_{\kappa p}^{\circ}=\operatorname{arctg} \frac{\left(0,1-0,152 / c M^{2}\right)}{\left(1,82 / c^{3}\right) \cdot 1 c M} \approx 5^{\circ}-7^{\circ},
\end{gathered}
$$

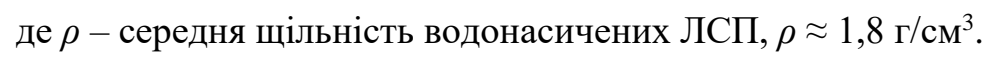


Наведені розрахунки цілком збігаються 3 фактичними даними щодо зростаючих випадків сучасного зсувоутворення в межах ПМА на схилах зі стрімкістю $5^{\circ}-7^{\circ}$, а також щодо суфозійних осідань поверхні біля будівель, місць скупчення транспорту, каналізаційних колодязів, тобто скрізь, де має місце інтенсивна техногенна інфільтрація та перезволоження лесових порід, активні динамічні зміни порового тиску, геомеханічного та фізико-хімічного стану порід підгрунтя будівель і верхньої зони ГС в містах і селищах.

Розвиток ділянок перезволоження та тиксотропних проявів у верхній частині геологічного розрізу лесових товщ обумовлює можливість формування у ній гідро-геодеформаційних полів та ослаблених зон у випадках впливу транзитних (зона Вранча, Крим) та техногенних (промислові вибухи, будівельні роботи тощо) землетрусів.

На прибережних територіях (зокрема в околицях м. Одеса) очікується збільшення прояву додаткового фактору ускладнення інженерно-геологічного стану лесів та ЛСП - підйому рівня моря та збільшення енергії хвиль під впливом глобальних змін клімату. Це має призводити до підвищення зони

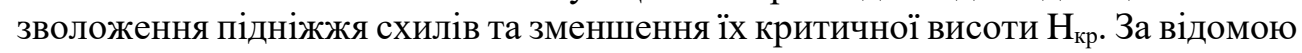
залежністю проф. М.А. Цитовича [14], критична висота вертикального схилу $\mathrm{H}_{\text {кр }}$, який складений грунтами із залишковим зчепленням у $\mathrm{C}=0,2$ кг $/ \mathrm{cm}^{2}$ та об'ємною густиною у $\gamma_{\mathrm{w}}=1,4$ г $\mathrm{cm}^{3}$, дорівнює:

$$
\mathrm{H}_{\mathrm{\kappa p}}=2 \cdot \mathrm{C} / \gamma_{\mathrm{w}}=2 \cdot 0,2 / 0,0014 \approx 3,0 \text { м. }
$$

Тобто комплексний вплив факторів сучасних глобальних змін клімату (потепління, збільшення зволоження та засолення) на верхню зону лесовопородного масиву, зокрема і на прибережно-морських територіях, призводить до збільшення площ зсувонебезпечних ареалів та інженерносейсмогеологічної вразливості споруд в їх межах (особливо в ПМА).

\section{Модель додаткового сейсмічного ризику на підтоплених лесах і ЛСП}

Для розрахунку значення додаткового сейсмічного ризику руйнування споруд на підтоплених лесах i ЛСП використана принципова модель такого регіонального ризику, наведена у [4].

$$
\mathrm{R}_{\mathrm{destr}}=\mathrm{N}_{\mathrm{dv}} \cdot \mathrm{Pm} \cdot \mathrm{k}_{\mathrm{N}} \cdot \mathrm{b} \cdot \mathrm{P}
$$

де: $\mathrm{N}_{\mathrm{dv}}$ - норма житлової площі на одну людину (приймається, що $12 \mathrm{~m}^{3}$ );

$\mathrm{Pm}$ - середня балансова вартість м² житлової площі (приймається, що \$1 тис.); $\mathrm{k}_{\mathrm{N}}$ - кількість населення на підтоплених лесах і ЛСП (осіб);

P - імовірність руйнівної події;

$\mathrm{b}$ - поправочний коефіцієнт ступеня пошкодження будівлі, залежний від інтенсивності струшувань I $(\mathrm{I}=6-6,9: \mathrm{b}=0,1 ; \mathrm{I}=7-7,9: \mathrm{b}=0,3 ; \mathrm{I}=8-8,9: \mathrm{b}=0,7$; $\mathrm{I} \geq 9$ балів: $\mathrm{b}=1)$.

Ця модель потребує уточнення, зокрема, в частині визначення імовірності (загрози) реалізації руйнівної події з урахуванням кліматичних параметрів та їхньої зміни. 
Імовірність сейсмічного поштовху та пов'язаного з ним формування поля змін напружено-деформованого стану (НДС) породного масиву розглядається нами як фіксована величина. Згідно 3 картою загального сейсмічного районування 3СР-2004 (карта В) вона становить $1 / 1000$ на рік $\left(\mathrm{p}_{\mathrm{s}}=10^{-3}\right.$ рік $\left.^{-1}\right)$ $[5$, c. 55,57$]$.

\section{Вплив кліматичних факторів на сейсмічний ризик руйнування споруд}

За висновками фахівців УкрНДГМІ, сучасні зміни клімату в Україні в частині опадів полягають у тому, що їх річний обсяг майже не змінився і в найближчі роки істотно не зміниться; натомість зросла (i продовжує зростати) нерівномірність опадів за сезонами та інтенсивністю: рідшають затяжні дощі, частішають екстремальні зливи в теплий сезон (травень - вересень). I все це на фоні зростання середньомісячних температур і посушливих періодів. Тобто загрози підтоплення на регіональному рівні чимдалі стають: а) яскраво сезонними; б) дискретизуються в часі і просторі; в) ареали цілорічного підтоплення зменшуються, особливо лесів і ЛСП, розміщених переважно у південній половині України (лісостепова і степова природні зони). Таке «сезонне» підтоплення, очевидно, спричиняється здебільшого весняними повенями та аномальними зливами.

Тобто для уточнення імовірності руйнівної події на лесах і ЛСП стає необхідним визначити кліматичну імовірність регіонального підтоплення. Ми пропонуємо здійснювати це на основі врахування середньорічної тривалості наслідків весняних повеней і аномальних злив. У першому наближенні їх припустимо розглядати як не пов'язані події (повені: березень - травень; зливи: травень - серпень).

Імовірність підтоплення внаслідок весняних повеней пропонуємо визначати так:

$$
\mathrm{p}_{\mathrm{fl}}=\mathrm{T}_{\mathrm{fl}} / 365 \text { piK }^{-1}
$$

де: $\mathrm{T}_{\mathrm{fl}}$ - середня багаторічна тривалість повені в регіоні, днів (оцінка за зональними і регіональними кліматичними узагальненнями $[6,7])$.

Імовірність підтоплення внаслідок аномальних злив пропонуємо визначати так:

$$
\mathrm{p}_{\mathrm{sh}}=\mathrm{T}_{\mathrm{sh}} \cdot \mathrm{t} /(365 \cdot 10) \text { рiк }^{-1}
$$

де: $\mathrm{T}_{\mathrm{sh}}-$ кількість зафіксованих в регіоні аномальних злив у 2001-2010 pр. згідно 3 [8];

$\mathrm{t}$ - тривалість підтоплення після аномальної зливи, днів (приймається, що $\mathrm{t}=14)$.

Із загальним потеплінням, викликаним зміною клімату, також пов'язане скорочення часу та глибини промерзання [9, с. 195, 197] верхньої зони лесовопородного масиву, що потенційно збільшує його водонасичення. Цей теоретичний висновок має бути підтверджений польовими спостереженнями за фрагментацією зсувних масивів та збільшенням в останні роки зсувних ділянок у вигляді потоків на уражених зсувами схилах у Карпатському регіоні, Придніпров’і, Криму тощо. 
На жаль, ми були вимушені використати дещо застарілі і неповні дані, оскільки, наприклад, інформація про тривалість весняних повеней та кількість аномальних злив в Україні у десятиліття 2010-2019 рр. досі не оприлюднена.

Тоді, оскільки сейсмічний поштовх і підтоплений стан лесів та ЛСП мають збігтися в часі, інтегральна імовірність руйнівної події такого типу становитиме:

$$
\mathrm{P}=\mathrm{p}_{\mathrm{S}} \bullet\left(\mathrm{p}_{\mathrm{fl}}+\mathrm{p}_{\mathrm{sh}}\right)
$$

Згідно з нашою оцінкою за даними наведених вище літературних джерел, інтегральна імовірність загрози руйнування споруд на підтоплених лесах $\mathrm{i}$ ЛСП (за сейсмічного поштовху інтенсивністю понад 6 балів) в середньому по Україні становитиме:

$\mathrm{P}_{\text {ua_kl }}=10^{-3} \cdot(0,137+0,031)=1,68 \cdot 10^{-4}$ рiк $^{-1}$.

В різних регіонах вона варіюватиме в інтервалі $1,23 \cdot 10^{-4} \div 2,58 \cdot 10^{-4}$ рiк $^{-1}$.

Однак відомо, що через зміни клімату, пов'язані з нестійкістю снігового покриву в зимовий період завдяки зростанню частоти і тривалості відлиг, тривалість весняної повені в Україні знижується, як знижується і повеневий стік [6, с. 199; 10, с. 46-47; 11, с. 97]. Ми спробували врахувати це у першому наближенні, зменшивши тривалість весняної повені в середньому на $36 \%$. Відповідно зменшиться і середньорічна імовірність підтоплення повенями та інтегральна імовірність руйнівної події в середньому по Україні до:

$\mathrm{P}_{\text {ua_ch }}=10^{-3} \cdot(0,087+0,031)=1,18 \cdot 10^{-4}$ piк $^{-1}$.

В регіонах вона варіюватиме в інтервалі 8,22 $10^{-5} \div 2,58 \cdot 10^{-4}$ рiк $^{-1}$.

Для розрахунку кількості населення в ареалах сумарної сейсмічності понад 6 балів, небезпечних для стійкості споруд (зони 6-6,9; 7-7,9; 8-8,9; 9 балів і більше), а також кількості населення на площах підтоплених лесів і ЛСП (у відповідних зонах сумарної сейсмічності) виконано картометричне дослідження засобами ГІС ArcMap 9.3. Кількість населення розрахована в розрізі регіонів України. Використана процедура перетину контурів, взятих з відповідних шарів оцифрованих тематичних карт:

- контурів поширення лесів і ЛСП, з «Карты условий развития экзогенных геологических процессов территории Украины» (М 1:1500000), Госкомгео, ГГП «Геопрогноз», Госгеолфонд Украины, 1994-1997;

- картографічний шар контурів розвитку регіонального підтоплення станом на 2004 р., скорегований за даними «Карти підтоплення території України» (М 1:1500000), ДНВП «Геоінформ України», 2016;

- контурів зон сумарної сейсмічності за дослідженнями проф. А.В. Лущика 3 «Карты-схемы влияния инженерно-геологических условий на техногенное приращение сейсмичности территории УССР» (М 1:1500000), 1990.

Кількість населення оцінена за сукупністю населених пунктів (міст і сіл), що потрапили у відповідні ареали, накладені на «Топографічну електронну карту України 3 інформацією Держкомстату про чисельність наявного населення України» М 1:200000 (перепис 2001 року). Версія 1.0. ДП «МЦЕК». Харків, 2004. 


\section{Оцінка додаткового сейсмічного ризику руйнування споруд на лесах і ЛСП}

Варіанти оцінки ризиків за формулами (3-6) розраховані в розрізі регіонів та для України в цілому (табл. 1).

Управлінський сенс грошової оцінки ризику полягає в тому, що саме стільки мають коштувати зусилля щодо зменшення загрози. В нашому випадку зусилля із запобігання підтопленню та підтримання сейсмостійкості будівель на відповідних територіях поширення лесів і ЛСП за еквівалентної інтенсивності сейсмічного поштовху.

Максимальна оцінка кількості населення на підтоплених лесах і ЛСП в зонах загальної сейсмічності понад 6 балів по Україні в цілому дорівнює 3,01 млн осіб (6,3\% від всього населення в зонах сумарної сейсмічності 6 і більше балів).

Таблиця 1 - Варіанти пілотної економічної оцінки додаткового ризику сейсмічного руйнування споруд на підтоплених лесах і ЛСП в Україні в цілому

\begin{tabular}{|c|c|c|c|c|c|c|}
\hline & \multirow{2}{*}{$\begin{array}{l}\text { Категорії регіонального } \\
\text { ризику, \$ млн рік }\end{array}$} & \multicolumn{5}{|c|}{ Сумарна сейсмічність, балів } \\
\hline & & $\begin{array}{c}6 \mathrm{i} \\
\text { більше }\end{array}$ & $6-6,9$ & $7-7,9$ & $8-8,9$ & $\begin{array}{c}9 \mathrm{i} \\
\text { більше }\end{array}$ \\
\hline 1 & $\begin{array}{c}\text { Загальний сейсмічний ризик } \\
\text { руйнування (без врахування } \\
\text { кліматичних параметрів) }\end{array}$ & 189,82 & 13,28 & 102,30 & 59,24 & 15,01 \\
\hline \multicolumn{7}{|c|}{ Додатковий сейсмічний ризик руйнування споруд на підтоплених лесах і ЛСП } \\
\hline 2 & $\begin{array}{l}\text { - без врахування кліматичних } \\
\text { параметрів }\end{array}$ & 13,88 & 0,54 & 6,18 & 6,89 & 0,27 \\
\hline 3 & \% від загального ризику & 7,3 & 4,1 & 6,0 & 11,6 & 1,8 \\
\hline 4 & $\begin{array}{l}\text { - } 3 \text { врахуванням кліматичних } \\
\text { параметрів }\end{array}$ & 2,32 & 0,091 & 1,03 & 1,15 & 0,045 \\
\hline 5 & $\begin{array}{l}\text { \% від ризику на підтоплених } \\
\text { лесах без врахування } \\
\text { кліматичних параметрів } \\
\end{array}$ & 16,8 & 16,8 & 16,8 & 16,8 & 16,7 \\
\hline 6 & $\begin{array}{l}\text { - у тому числі з врахуванням } \\
\text { зменшення тривалості } \\
\text { весняної повені }\end{array}$ & 1,64 & 0,064 & 0,73 & 0,81 & 0,032 \\
\hline 7 & $\begin{array}{l}\text { \% від ризику на підтоплених } \\
\text { лесах без врахування } \\
\text { кліматичних параметрів }\end{array}$ & 11,8 & 11,85 & 11,8 & 11,8 & 11,85 \\
\hline
\end{tabular}

Джерело: авторські розрахунки.

Максимальна оцінка (без врахування кліматичних параметрів) додаткового ризику руйнування споруд на підтоплених лесах і ЛСП за сейсмічного поштовху 6 балів і більше становитиме приблизно 13,9 \$ млн рік ${ }^{-1}$.

Середня оцінка (з врахуванням кліматичних параметрів) - 2,3 \$ млн рік . $^{-1}$

Мінімальна оцінка (з врахуванням зменшення тривалості весняної повені) 1,6 \$ млн рік ${ }^{-1}$.

Це становить, відповідно, 7,3\%, 1,2\%, 0,8\% від загального ризику руйнування споруд, розрахованого для зон сумарної сейсмічності згідно 3 оцінками проф. А.В. Лущика з інтенсивністю сейсмічного поштовху 6 балів і більше - 189,8 \$ млн рік-1 (без врахування кліматичних параметрів). 
Регіоном із найбільшим додатковим сейсмічним ризиком руйнування споруд на підтоплених лесах і ЛСП $є$ Одеська область - 41,5-60\% від загальноукраїнського значення ризику в зоні сумарної сейсмічності 6 балів i більше за розрахованими варіантами оцінки. В цьому регіоні переважна частина такого ризику пов'язана з 8-8,9-бальною сумарною сейсмічністю, табл. 2.

Таблиця 2 - Регіональна оцінка додаткового ризику руйнування споруд на підтоплених лесах і ЛСП в Україні у зоні сумарної сейсмічності 6 балів і більше

\begin{tabular}{|c|c|c|c|c|c|c|c|c|c|c|c|c|c|c|c|c|}
\hline \multirow{3}{*}{ № } & \multirow{3}{*}{ Області } & \multicolumn{15}{|c|}{ Варіанти оцінки ризику } \\
\hline & & \multicolumn{5}{|c|}{$\begin{array}{c}\text { Без врахування } \\
\text { кліматичних } \\
\text { параметрів }\end{array}$} & \multicolumn{5}{|c|}{$\begin{array}{c}3 \text { врахуванням } \\
\text { кліматичних } \\
\text { параметрів }\end{array}$} & \multicolumn{5}{|c|}{$\begin{array}{c}\text { У т.ч. } 3 \text { врахуванням } \\
\text { зменшення тривалості } \\
\text { весняної повені }\end{array}$} \\
\hline & & $\begin{array}{c}\text { Всього } \\
\geq 6\end{array}$ & 6-6,9 & $7-7,9$ & $8-8,9$ & $\geq 9$ & $\begin{array}{c}\text { Всього } \\
\geq 6\end{array}$ & $6-6,9$ & $7-7,9$ & $8-8,9$ & $\geq 9$ & $\begin{array}{c}\text { Всього } \\
\geq 6\end{array}$ & $6-6,9$ & $7-7,9$ & $8-8,9$ & $\geq 9$ \\
\hline 1 & Крим & 384 & 2 & 328 & 55 & 0 & 99 & 0 & 85 & 14 & 0 & 99 & 0 & 85 & 14 & 0 \\
\hline 2 & Вінницька & 305 & 3 & 27 & 102 & 173 & 48 & 0 & 4 & 16 & 27 & 31 & 0 & 3 & 10 & 18 \\
\hline 3 & Волинська & 0 & 0 & 0 & 0 & 0 & 0 & 0 & 0 & 0 & 0 & 0 & 0 & 0 & 0 & 0 \\
\hline 4 & Донецька & 263 & 78 & 185 & 0 & 0 & 39 & 11 & 27 & 0 & 0 & 28 & 8 & 19 & 0 & 0 \\
\hline 5 & Дніпровська & 1376 & 10 & 1322 & 43 & 0 & 217 & 2 & 209 & 7 & 0 & 161 & 1 & 154 & 5 & 0 \\
\hline 6 & Житомирська & 590 & 10 & 580 & 0 & 0 & 121 & 2 & 119 & 0 & 0 & 73 & 1 & 71 & 0 & 0 \\
\hline 7 & Закарпатська & 0 & 0 & 0 & 0 & 0 & 0 & 0 & 0 & 0 & 0 & 0 & 0 & 0 & 0 & 0 \\
\hline 8 & Запорізька & 430 & 19 & 411 & 0 & 0 & 65 & 3 & 62 & 0 & 0 & 47 & 2 & 45 & 0 & 0 \\
\hline 9 & Ів.-Франківська & 8 & 0 & 3 & 6 & 0 & 1 & 0 & 0 & 1 & 0 & 1 & 0 & 0 & 1 & 0 \\
\hline 10 & Київська & 63 & 3 & 53 & 8 & 0 & 12 & 1 & 10 & 1 & 0 & 7 & 0 & 6 & 1 & 0 \\
\hline 11 & Кропивницька & 25 & 0 & 25 & 0 & 0 & 4 & 0 & 4 & 0 & 0 & 3 & 0 & 3 & 0 & 0 \\
\hline 12 & Луганська & 3 & 3 & 0 & 0 & 0 & 0 & 0 & 0 & 0 & 0 & 0 & 0 & 0 & 0 & 0 \\
\hline 13 & Львівська & 16 & 16 & 0 & 0 & 0 & 2 & 2 & 0 & 0 & 0 & 2 & 2 & 0 & 0 & 0 \\
\hline 14 & Миколаївська & 431 & 2 & 400 & 29 & 0 & 71 & 0 & 66 & 5 & 0 & 54 & 0 & 50 & 4 & 0 \\
\hline 15 & Одеська & 5765 & 0 & 364 & 5307 & 94 & 1235 & 0 & 78 & 1137 & 20 & 982 & 0 & 62 & 814 & 16 \\
\hline 16 & Рівненська & 11 & 0 & 11 & 0 & 0 & 2 & 0 & 2 & 0 & 0 & 1 & 0 & 1 & 0 & 0 \\
\hline 17 & Сумська & 128 & 101 & 27 & 0 & 0 & 21 & 16 & 4 & 0 & 0 & 12 & 9 & 2 & 0 & 0 \\
\hline 18 & Полтавська & 1217 & 107 & 1105 & 6 & 0 & 191 & 17 & 174 & 1 & 0 & 128 & 11 & 116 & 1 & 0 \\
\hline 19 & Тернопільська & 0 & 0 & 0 & 0 & 0 & 0 & 0 & 0 & 0 & 0 & 0 & 0 & 0 & 0 & 0 \\
\hline 20 & Харківська & 480 & 45 & 435 & 0 & 0 & 77 & 7 & 70 & 0 & 0 & 52 & 5 & 47 & 0 & 0 \\
\hline 21 & Херсонська & 220 & 120 & 100 & 0 & 0 & 35 & 19 & 16 & 0 & 0 & 26 & 14 & 12 & 0 & 0 \\
\hline 22 & Хмельницька & 3 & 3 & 0 & 0 & 0 & 0 & 0 & 0 & 0 & 0 & 0 & 0 & 0 & 0 & 0 \\
\hline 23 & Черкаська & 90 & 6 & 31 & 54 & 0 & 15 & 1 & 5 & 9 & 0 & 10 & 1 & 3 & 6 & 0 \\
\hline 24 & Чернівецька & 1341 & 0 & 58 & 1283 & 0 & 192 & 0 & 8 & 183 & 0 & 151 & 0 & 7 & 145 & 0 \\
\hline 25 & Чернігівська & 731 & 15 & 716 & 0 & 0 & 147 & 3 & 144 & 0 & 0 & 69 & 1 & 67 & 0 & 0 \\
\hline \multicolumn{2}{|c|}{ Україна всього } & 13882 & 544 & 6180 & 6891 & 267 & 2324 & 91 & 1034 & 1153 & 45 & 1638 & 64 & 729 & & \\
\hline
\end{tabular}

Джерело: авторські розрахунки.

Підвищений додатковий сейсмічний ризик руйнування на підтоплених лесах і ЛСП, переважно пов'язаний 3 зоною 8-8,9-бальної сумарної сейсмічності, спостерігається також у Чернівецькій області $(9,2-9,7 \%$ від загальноукраїнського значення ризику). А переважно пов'язаний з зоною 7-7,9-бальної сумарної сейсмічності - в Дніпровській (9,3-9,9\%) та Полтавській областях (7,8-8,8\% від загальноукраїнського значення ризику). 
В інших регіонах України за розрахованими варіантами оцінки локалізовано 11,6-32,2\% загальноукраїнського значення додаткового сейсмічного ризику руйнування споруд на підтоплених лесах і ЛСП (за винятком Волинської та Тернопільської областей, де він дорівнює нулю).

\section{Висновки}

1. Отримані дані про сучасну активізацію змін інженерно-геологічних умов лесів і ЛСП та збільшення їх внеску у зростання еколого-геологічних ризиків життєдіяльності підводять до важливого висновку, що лесово-породні масиви у більшості регіонів України стають найбільш чутливим елементом геологічного середовища до впливу зростаючого техногенного навантаження та глобальних змін клімату.

2. До посилення небезпечних властивостей лесів та ЛСП, крім просадковості, зменшення міцності тощо, додалися нові процеси - активізація набухаємості, збільшення проявів пливуноутворення та тиксотропії. Найактивніше вони проявляються в містах і селищах, що обумовлено великими втратами води і тепла з міських мереж, які сягають 35-45\% і перевищують фільтраційну здатність лесів та ЛСП. У більшості випадків це призводить до формування техногенних водоносних горизонтів (так званих «верховодок») як ключового чинника в механізмі деградації лесово-породних товщ у містах та формування гідро-геодеформаційних полів при сейсмопоштовхах.

3. Врахування кліматичних параметрів істотно змінює значення економічної оцінки додаткового ризику сейсмічного руйнування споруд на підтоплених лесах і ЛСП в Україні у бік його зменшення на локальнооб'єктовому рівні. Врахування їх зміни в останні десятиліття зменшує такий ризик ще більше, оскільки на фоні стійкої тенденції до зростання середніх температур відбувається дискретизація опадів в часі і просторі, збільшення частоти аномальних злив, зменшення стійкості снігового покрову (відлиги) i тривалості весняних повеней, що призводить до такої ж дискретизації регіонального підтоплення.

4. До врахованих нами на цьому етапі дослідження кліматичних параметрів доцільно додати також: кількість днів 3 дощем за рік та кількості днів із не замерзлим грунтом в зимовий період (листопад - лютий).

5. Все більше актуалізується потреба у здійсненні регіонального аналізу зміни зазначених кліматичних параметрів за останні 10 і 20 років та в організації постійного моніторингу за ними силами УкрНДГМІ із публікацією відповідних річних звітів на Інтернет-сайті цього інституту.

6. Не менш важливо здійснювати щорічний просторовий моніторинг регіонального підтоплення (з оцінкою площ в регіональному розрізі) та оприлюднення табличних і картографічних результатів спостереження.

7. Швидкі зміни інженерно-геологічного стану просадкових породних масивів в умовах впливу чинників глобальних змін клімату, зростання глобальної сейсмічності та техногенезу, на нашу думку, потребують розробки нових нормативно-методичних положень 3 вивчення лесових та лесовопородних формацій із виділенням їх опорних розрізів у техногенно навантажених та вразливих регіонах України, зокрема у ії найбільших містах. 


\section{СПИСОК ЛІТЕРАТУРИ}

1. Рогожин О.Г., Яковлев Є.О. Потенційний приріст сейсмічності в Україні як фактор зростання ризику життєдіяльності від аварій на хіміко-небезпечних ПНО / О.Г. Рогожин, С.О. Яковлев // Екологічна безпека та природокористування. - 2015. Вип. 1(17). - С. 15-27.

2. Яковлев Є.О., Рогожин О.Г. Фактори і можливі наслідки регіональних змін інженерно-геотехнічного стану лесів та лесово-суглинистих порід України / Є.О. Яковлев, О.Г. Рогожин // Екологічна безпека та природокористування. - 2018. Вип. 3(27). - С. 5-23.

3. П’яте національне повідомлення України з питань зміни клімату. Мінприроди України. Київ, 2009. - 281 с.

4. Яковлев Є.О., Рогожин О.Г., Васинюк А.В. ГІС-оцінка загроз погіршення інженерно-геотехнічного стану лесів та лесово-суглинистих порід України в умовах глобальних змін клімату / Є.О. Яковлев, О.Г. Рогожин, А.В. Васинюк // Інформаційні технології управління екологічною безпекою, природокористуванням, заходами в надзвичайних ситуаціях: Колективна монографія за матеріалами XVII Міжнародної науково-практичної конференції (Київ, 25-26 вересня 2018 р.) - К: ТОВ «Вид. «Юстон», 2018. - С. 154-156.

5. ДБН В.1.1.-12: 2006. : Додаток В. - 82 с.

6. Сусідко М.М., Лук'янець О.I. Районування території України за ступенем гідрологічної небезпеки / М.M Сусідко, О.І. Лук'янець // Наук. праці УкрНДГМІ. 2004. - Вип. 253. - С. 196-204.

7. Національний атлас України. Поверхневі води та водні ресурси. Текст / B.I. Осадчий, A.I. Шерешевський [Електронний ресурс] Режим доступу: http://wdc.org.ua/atlas/4090100.html

8. Гребенюк Н.П. Характеристика повторюваності сильних злив на території України в умовах сучасних змін клімату / Н.П. Гребенюк // Гідрологія, гідрохімія і гідроекологія. - 2014. - Т.1(32). - С. 96-101.

9. Василенко Є.В. Основні чинники формування весняного водопілля в басейні р. Прип’ять та їхні сучасні зміни / С.В. Василенко // Наук. праці УкрНДГМІ. - 2011 Вип. 261. - С. 192-198.

10.Гребінь В.В. Оцінка водності річок басейну верхньої Прип`яті в умовах кліматичних змін / В.В. Гребінь // Гідрологія, гідрохімія і гідроекологія. - 2011. T.4(25). - C. 38-48.

11. Бібік В.В., Винарчук О.О., Лук`янець О.І., Хільчевський В.К. Просторово-часова характеристика стоку річок басейнів Сула, Псел, Ворскла / В.В. Бібік, О.О. Винарчук, О.І. Лук`янець, В.К. Хільчевський // Гідрологія, гідрохімія і гідроекологія. - 2011. T.4(25). - C. 85-99.

12. Трофимчук О.М., Яковлєв С.О., Закорчевна Н.Б., Госк Е. Регіональне підтоплення міст та селищ України як фактор ії національної безпеки. // Екологія довкілля та безпека життєдіяльності. - К. - 2003. - №6. - С. 12-23.

13. Трофимов В.Т., Королев В.А. (ред.). Инженерная геология массивов лёссових пород. - М. МГУ, 2004. - 139 с.

14. Цытович Н.А. Механика грунтов. - М. - Высш. школа. - 1983. - 288 с.

Стаття надійшла до редакиії 02.08.2019 і прийнята до друку після рецензування 29.08.2019 


\section{REFERENCES (TRANSLATED AND TRANSLITERATED)}

1. Rogozin, O. G., \& Yakovlev, Y. O. (2015). Potential increase of seismicity in Ukraine as a factor of growth of personal and social safety risk from accidents on chemically dangerous objects. Environmental Safety and Natural Resources , 17(1), 15-27. (in Ukrainian).

2. Yakovlev, Y., \& Rogozin, O. (2018). The factors and possible consequences of regional changes in engineering and geotechnical status of loesses and loessy-loamy soils of Ukraine. Environmental Safety And Natural Resources, 27(3), 5-23. doi:http://dx.doi.org/10.32347/2411-4049.2018.3.5-23. (in Ukrainian).

3. Fifth national message from Ukraine on climate change. (2009). Ministry of Environment of Ukraine. Kyiv, Ukraine (281 p.). (in Ukrainian).

4. Yakovlev, Y. O., Rohozhyn, O. H., \& Vasyniuk, A. V. (2018). GIS-otsinka zahroz pohirshennia inzhenerno-heotekhnichnoho stanu lesiv ta lesovo-suhlynystykh porid Ukrainy $\mathrm{v}$ umovakh hlobalnykh zmin klimatu. In XVII Mizhnarodna naukovo-praktychna konferentsiia "Informatsiini tekhnolohii upravlinnia ekolohichnoiu bezpekoiu, pryrodokorystuvanniam, zakhodamy v nadzvychainykh sytuatsiiakh». (Kyiv, 25-26 veresnia 2018 r.) (pp. 154-156). Kyiv: «Vyd. «Iuston». (in Ukrainian).

5. DBN B.1.1.-12: 2006. Addition B. - 82 p. (in Ukrainian).

6. Susidko, M. M., \& Luk'ianets, O. I. (2004). Zoning of the territory of Ukraine by the degree of hydrological danger. Naukovi Pratsi UkrNDHMI, (253), 196-204. (in Ukrainian).

7. Osadchyj, V. I., \& Shereshevs'kyj, A. I. (n.d.). National Atlas of Ukraine. Surface water and water resources. Text. Retrieved from http://wdc.org.ua/atlas/4090100.html. (in Ukrainian).

8. Hrebeniuk, N. P. (2014). Characteristic of the recurrence of heavy rainfall in Ukraine in the context of modern climate change. Hydrology, hydrochemistry and hydroecology, 32(1), 96-101. (in Ukrainian).

9. Vasylenko, Y. V. (2011). The main factors for the formation of spring waterfalls in the Pripyat River basin and their modern changes. Naukovi Pratsi of UkrNDHMI, (261), 192198. (in Ukrainian).

10. Hrebin, V. V. (2011). Assessment of the water quality of the rivers of the upper Pripyat basin in the climate change. Hydrology, Hydrochemistry and Hydroecology, 4(25), 38-48.

11. Bibik, V. V., Vynarchuk, O. O., Luk ianets, O. I., \& Khilchevskyi, V. K. (2011). Spatiotemporal characteristics of runoff of the Sula, Psel, and Vorskla basins. Hydrology, Hydrochemistry and Hydroecology, 4(25), 85-99. (in Ukrainian).

12. Trofymchuk, O. M., Yakovliev, Y. O., Zakorchevna, N. B., \& Hosk, E. (2003). Regional flooding of Ukrainian cities and towns as a factor of its national security. Environmental Ecology and Life Safety, (6), 12-23. (in Ukrainian).

13. Trofymov, V. T. (2004). Engineering geology of loess-rock massifs. (V. A. Korolev, Ed.). Moscow: MGU. (In Russian).

14. Cytovych, N. A. (1983). Soil mechanics. Moscow: Vyssh. Shkola. (In Russian).

The article was received 02.08.2019 and was accepted after revision 29.08.2019

\section{Рогожин Олексій Георгійович}

доктор економічних наук, головний науковий співробітник Інституту телекомунікацій і глобального інформаційного простору НАН України

Адреса робоча: 03186 Україна, м. Київ, Чоколівський бульвар, 13

e-mail: olexarog@gmail.com

ORCID ID 0000-0001-8101-9368

\section{Яковлев Свген Олександрович}

доктор технічних наук, головний науковий співробітник Інституту телекомунікацій i глобального інформаційного простору НАН України

Адреса робоча: 03186 Україна, м. Київ, Чоколівський бульвар, 13

e-mail: yakovlev@niss.gov.ua 